\title{
細線熱電対群の応答補償と変動温度場の多次元計測への適用*
}

\author{
田川正人*1, 貝吹 和 秀*2, 保 浦 知 也*1 \\ 山上洋介 ${ }^{* 3}$, 加藤健 次*4
}

\section{Response Compensation of Fine-Wire Thermocouples and Its Application to Multidimensional Measurement of a Fluctuating Temperature Field}

\author{
Masato TAGAWA*5, Kazuhide KAIFUKU, Tomoya HOURA, \\ Yosuke YAMAGAMI and Kenji KATO \\ *5 Department of Mechanical Engineering, Nagoya Institute of Technology, \\ Gokiso-cho, Showa-ku, Nagoya-shi, Aichi, 466-8555 Japan
}

\begin{abstract}
A novel sensor technique is proposed to visualize the readily spatiotemporal behavior of a fluctuating temperature field of airflow. Two temperature probes were fabricated: one is a rod-type probe consisting of 24 two-thermocouple sensors set in line and the other is a plane-type one consisting of 64 two-thermocouple sensors arrayed on a two-dimensional grid $(8 \times 8$ points). Each two-thermocouple sensor used in these probes was composed of two fine-wire thermocouples (type K) of unequal diameters, e.g., $25 \mu \mathrm{m}$ and $51 \mu \mathrm{m}$. An adaptive response-compensation scheme was applied to accurately reconstruct rapidly-changing airflow temperatures. The plane-type probe enables visualization of fluctuating temperature fields of an artificially disturbed hot-air jet and adequate capture of the spatiotemporal behavior of a rapid circular motion of hot-air jet blown out from a hair dryer. A time-constant estimation scheme was proposed to estimate instantaneous timeconstants which serve as a basis for a real-time response compensation technique for multidimensional temperature measurement. In addition, by scanning a temperature field with the rod-type probe, the temperature distribution can be reconstructed in one-dimensional space and time. This quasi two-dimensional visualization can become a prototype of a "scanner" for fluid temperature fields.
\end{abstract}

Key Words: Sensor, Flow Measurements, Turbulent Flow, Heat Transfer, Flow Visualization

\section{1. 緒言}

空気や水などの流体の温度分布をその場で簡単に可 視化できれば，熱や流体が関与する機器の開発設計や 性能評価における様々な場面で有用な情報を得ること ができる. 流体温度の空間分布を可視化する方法には， レーザや超音波による非接触計測法がある。非接触法 は原理的に優れているが，一般に，計測システムが複 雑であり，その使用には相当の専門知識を必要とする (1).また，適用できる場に強い制約があることが多く， とりわけレーザ応用計測では安全性に特別の配慮が求 められることもあって，実用レベルで普及する段階に は至っていない，このようなことから，流体の温度分 布を簡便かつ安全に可視化する技術が求められている。

\footnotetext{
* 原稿受付 2009 年 10 月 28 日.

*I 正員, 名古屋工業大学大学院機能工学専攻 (\$ 466-8555 名 古屋市昭和区御器所町).

*2 正員, 名古屋工業大学大学院 [現：トヨ夕紡織(株)].

*3 名古室工業大学大学院 [現：(株) デンソー].

*4 正員, 名古屋工業大学大学院 [現：三菱電機(株)].

E-mail : m.tagawa@ nitech.ac.jp
}

本研究では，取り扱いが容易で信頼性の高い「細 線温度センサ ${ }^{(2)} 」 を$ 基礎とする流体温度場の可視化計 測法を提案する．細線温度センサは，一般に，素線径 13 100 $\mu \mathrm{m}$ の熱電対 (細線熱電対) または線径 0.6 10 $\mu \mathrm{m}$ の金属細線（測温抵抗体）の総称である。なかで も細線熱電対は手軽で安価であるとともに，静特性を 校正する必要がなく適用範囲も広いことから様々な分 野で普及している．しかし，流体温度が高速で変化す る場合には，センサの出力が温度変化に追従できずに 応答遅れ（利得の低下と位相のずれ）が生じる．この ために，細線温度センサを利用して流体温度場を可視 化する場合にはこの問題を解決する必要がある.

応答遅れの問題は, 基本的には, センサの出力を適 切に応答補償し，実質的な応答速度を向上させること で解決される. しかし，応答補償に必要な時定数はセ ンサ周りの流体の物性や速度に強く依存するために， 時定数の值を正確に推定することは難しい，すなわち， 応答補償における本質的な課題は時定数值の正確な推 定にある。 
著者らは，長年この問題に取り組み，その解決策と して合理的な時定数推定法とそれに基づく応答補償法 を幾つか提案してきた ${ }^{(3)}$. 以下では, これらを適応応 答補償と総称する. 適応応答補償は, 具体的には, 次 の3つの要素から構成される. すなわち, 1) 応答速度 が異なる $2 つ の$ 細線熱電対を一対に組み合わせて一つ のセンサを構成するプローブ技術 (二線式熱電対) ${ }^{(4)}$, 2) センサの出力（測定データ）から時定数を推定する 同定理論, 3) 応答遅れを補償するディジタル信号処理 技術,である，適応応答補償を用いれば，センサの動 特性を校正する必要はなく, その実質的な応答速度を $10 \sim 100$ 倍に高めることができる(2).

本研究では, 上記の適応応答補償法を細線熱電対群 に適用して, 空気流の温度場を可視化する方法を提案 する. 最初に， 64 個の二線式熱電対を二次元格子点 （8×8）上に配置した平面プローブを製作し, 各格子点 の測定データに適応応答補償を適用寸ることによって, 二次元温度分布の時空間的挙動を正しく捕捉できるこ とを示す. 次いで, 時定数推定法を進展させて, 従来 のようにデータ収集後の後処理で時定数を推定し応答 補償するのではなく，ほぼ実時間で時定数の推定と応 答補償を行う新しい方法を提案するとともに, 従来法 と比較してその有效性を検証する. 最後に, 24 個の二 線式熱電対を直線上に等間隔で配置した棒状プローブ を製作し，これで高温気流をスキャンすることによっ て温度場を二次元で可視化する「流体温度場スキャナ」 の原型を提示する.

\section{2. 記 号}

$d:$ 素線の直径 $[\mathrm{m}]$

$f:$ 周波数 $[\mathrm{Hz}]$

$T:$ 温度 $[\mathrm{K}]$

$t:$ 時間 [s]

$\tau:$ 時定数 $[\mathrm{s}]\left[\equiv\left(2 \pi f_{\mathrm{c}}\right)^{-1}, f_{\mathrm{c}}\right.$ : 遮断周波数 $]$

添 字

$$
\begin{aligned}
& 1,2: \text { 素線径が異なる } 2 \text { つの熱電対 } \\
& \mathrm{g}: \text { : センサ周囲の流体 }
\end{aligned}
$$

\section{3. 細線熱電対の応答補償}

細線熱電対の応答特性は一般に次の 1 次遅れ系で近 似される(5).

$$
T_{\mathrm{g}}=T+\tau \frac{\mathrm{d} T}{\mathrm{~d} t}
$$

ここで, $T_{\mathrm{g}}$ は測定対象となる流体温度, $T$ は熱電対の 出力 (測定值), $\tau$ は時定数である. 時定数 $\tau$ の值を知 れば, 式(1)より熱電対の出力 $T$ から流体温度 $T_{\mathrm{g}}$ を 求めることができる.
著者らは, 応答速度（ここでは細線熱電対の素線径） が異なる2つの熱電対を一対にしてプローブを構成す る「二線式熱電対」を用いて，測定される時系列デー タから各センサの時定数を推定する 4 つの方法 ${ }^{(3)}$ を見 いだし, その有効性を様々な条件下で検証してきた. 本研究では，その中で時定数推定法の基本である $e_{\min }$ 法 ${ }^{(4)}$ を線式熱電対に適用して, 応答遅れを補償する.

二線式熱電対の応答特性は次式で与えられる.

$$
\left.\begin{array}{l}
T_{\mathrm{g} 1}=T_{1}+\tau_{1} \frac{\mathrm{d} T_{1}}{\mathrm{~d} t} \\
T_{\mathrm{g} 2}=T_{2}+\tau_{2} \frac{\mathrm{d} T_{2}}{\mathrm{~d} t}
\end{array}\right\}
$$

2 つの熱電対が同一の流体温度 $T_{\mathrm{g}}$ を感知している理 想的な状況 $\left(T_{\mathrm{g} 1}=T_{\mathrm{g} 2}=T_{\mathrm{g}}\right)$ であっても, 式(2)の 2 つの方程式には 3 つの未知量 $T_{\mathrm{g}}, \tau_{1}, \tau_{2}$ が存在するた めに，このままでは時定数 $\tau_{1}, \tau_{2}$ を決定できない．そ こで, 式 (2) 左辺の $T_{\mathrm{g} 1}$ と $T_{\mathrm{g} 2}$ の差の二乗平均值

$$
e=\overline{\left(T_{\mathrm{g} 2}-T_{\mathrm{g} 1}\right)^{2}}
$$

が最小となるように, 式(3)に最小二乗法を適用すれ ば時定数 $\tau_{1}, \tau_{2}$ を決定できる [( ) は時間平均を表す］。 したがって, 二乗平均值 $e$ を最小化する $\tau_{1}, \tau_{2}$ は次の 条件で得られる.

$$
\frac{\partial e}{\partial \tau_{1}}=0, \quad \frac{\partial e}{\partial \tau_{2}}=0
$$

その結果は次式で与えられる(4).

$$
\left.\begin{array}{c}
\tau_{1}=\frac{\overline{G_{2}^{2}} \cdot \overline{G_{1} \Delta T_{21}}-\overline{G_{1} G_{2}} \cdot \overline{G_{2} \Delta T_{21}}}{\overline{G_{1}^{2}} \cdot \overline{G_{2}^{2}}-\left(\overline{G_{1} G_{2}}\right)^{2}} \\
\tau_{2}=\frac{\overline{G_{1} G_{2}} \cdot \overline{G_{1} \Delta T_{21}}-\overline{G_{1}^{2}} \cdot \overline{G_{2} \Delta T_{21}}}{\overline{G_{1}^{2}} \cdot \overline{G_{2}^{2}}-\left(\overline{G_{1} G_{2}}\right)^{2}}
\end{array}\right\}
$$

ここで, $G, \Delta T_{21}$ はそれぞれ温度の時間微分 $G=\mathrm{d} T / \mathrm{d} t$ と温度差 $\Delta T_{21}=T_{2}-T_{1}$ を表す。

\section{4. 二次元細線熱電対群による变動温度場の計測}

4.1 二次元細線熱電対群プローブ 使用した二次 元細線熱電対群プローブの写真とその構成を図 1 に示 す. 図 1(b) に示すように, 各測定点では素線径 $d_{1}=25$ $\mu \mathrm{m}$ と $d_{2}=51 \mu \mathrm{m}$ の 2 つ $\mathrm{K}$ 熱電対で二線式熱電対 が構成される. 二線式熱電対を構成する 2 つの熱電対 は互いに干涉しない範囲で可能な限り接近するように 約 $0.5 \mathrm{~mm}$ の間隔で配置される（線間隔の影響につい ては付録を参照).二線式熱電対は互いに $20 \mathrm{~mm}$ の間 隔で $64(=8 \times 8)$ の格子点上に設置されている. 合計 128 個の K 熱電対の熱起電力は計測アンプで約 800 倍 に増幅されて, 8 台 $(16 \mathrm{ch} /$ 台 $)$ の $\mathrm{A} / \mathrm{D}$ 変換器により パーソナルコンピュータに取り込まれる. 以下では, 添字 1, 2 はそれぞれ素線径 $25 \mu \mathrm{m}, 51 \mu \mathrm{m}$ の $\mathrm{K}$ 熱電対 を表す. 


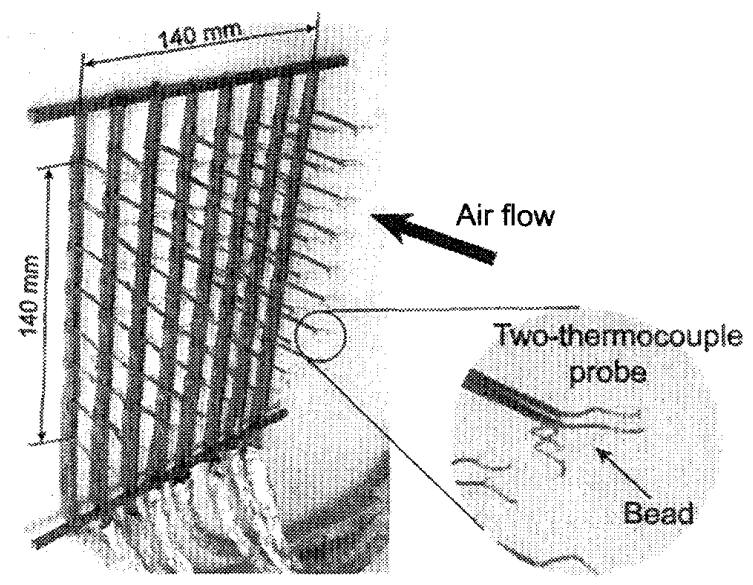

(a) Photograph

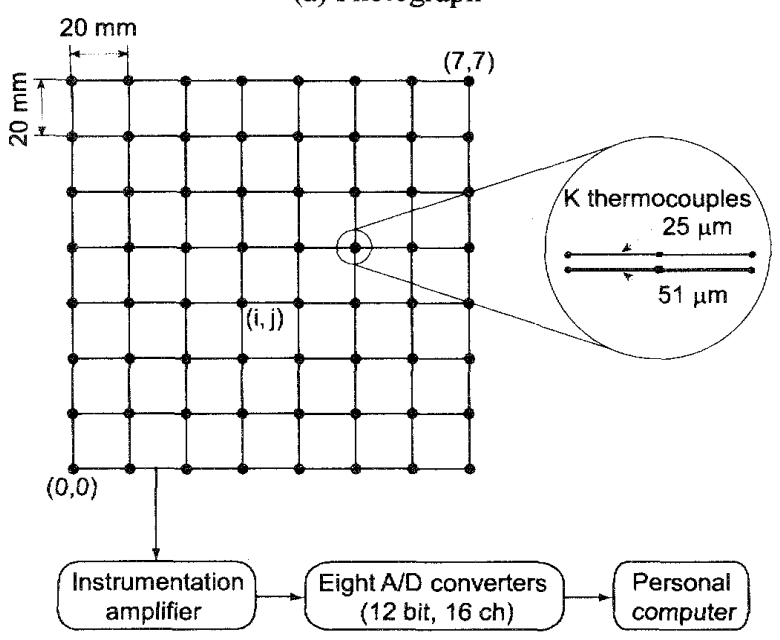

(b) Configration

Fig. 1 Two-dimensional probe for measuring a fluctuating temperature field (each grid point consists of a two-thermocouple probe)

\section{2 円柱により擋乱された円形噴流温度場の可視化}

計測実験装置の構成を図 2 に示す。测定対象は, 直径 $55 \mathrm{~mm}$ の円形ノズルから噴出する高温空気流（流 速 $5 \mathrm{~m} / \mathrm{s}$, 温度 $52{ }^{\circ} \mathrm{C}$ でほぼ一様）を人為的に擋乱す ることで発生する変動温度場である。周囲温度は 22 ${ }^{\circ} \mathrm{C}$ である．擋乱は，風洞とプローブとの間に置かれ た直径 $30 \mathrm{~mm}$ の円柱棒を $0.2 \mathrm{~s}$ 程度の周期で摇動させ ることで導入される，测定プローブは，測定面が噴流 軸に垂直になるように風洞出口から $70 \mathrm{~mm}$ 下流に設 置した。本実験では，データのサンプリング周波数は $1 \mathrm{kHz}$ ，データ長は各熱電対あたり 5120 点である。

最初に，本実験における応答補償の妥当性を検証す る. 図 3 にプローブ格子点 $(i, j)=(4,5)$ [図 1(b) 参照] で得られた温度変動波形を示す. 図 3 の上段は応答補 償前の変動波形 $T_{1}, T_{2}$ であり，下段は式 (2)による心 答補償後の温度波形 $T_{\mathrm{g} 1}, T_{\mathrm{g} 2}$ である. 応答補償では, 式 (5) で推定された時定数值 $\tau_{1}=19.5 \mathrm{~ms}, \tau_{2}=51.3 \mathrm{~ms}$ を式(2)に適用した。図 3 から分かるように, 応答補

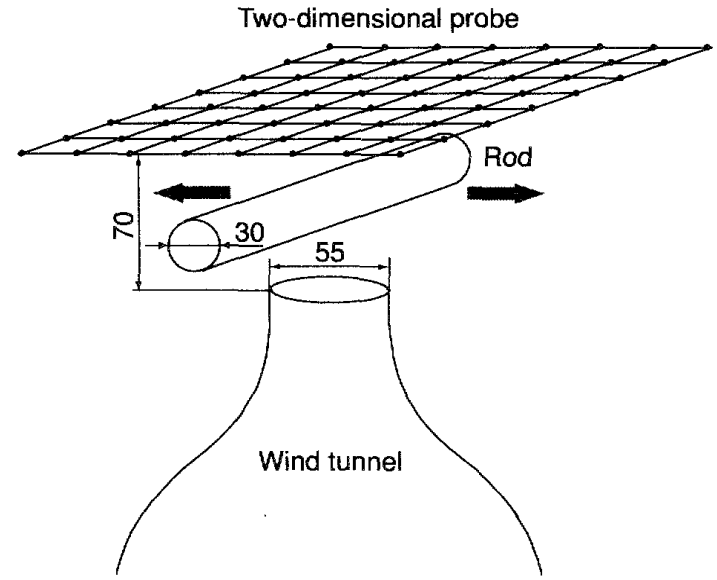

Fig. 2 Wind tunnel for providing an artificially disturbed hot-air jet to test a two-dimensional temperature probe

償によって変動温度の高周波数成分が正しく再生され て，2つの熱電対の波形は互いによく一致する．他の 測定点についても，流速等の差異に忘じてそれぞれの 点で時定数が適切に推定される，その結果，適応応答 補償が図 3 と同様に有効であることを確認した。

次に，円柱棒によって擋乱された温度場を空間二次 元で可視化し図 4 に示す。ここでは，応答補償の有効 性をより明確に提示するために，态答速度の低い素線 径 $51 \mu \mathrm{m}$ の熱電対群により測定された温度場の等高線 分布を示した。図 4(a), (b) はそれぞれ応答補償前と

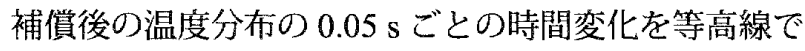
表示している。図4(a)では, 熱電対の応答遅れのため に温度場の擋乱がほとんど捕捉されずに，プローブの 中心付近にピークをもつ同心円状の温度分布（円形噴 流の平均温度分布を反映）が大きく崩れることなく保 持されている。一方，応答補償後の温度分布を示す図 4(b) では，円柱棒による擋乱に応答してプローブ中心 付近の温度場は顕著に変化している.とくに, $t=0.10$ $\mathrm{s}$ の等高線から分かるように, 円柱棒が高温噴流の中 心を横切るときに，周囲の低温流体が円柱棒の移動に 伴って噴流中心に巻き达まれる様子が明確に捕捉され ている.

$4 \cdot 3$ 移動する高温空気噴流の可視化計測 次に, 移動する高温空気噴流の軌道を捉えることを目的とし て, ヘアドライヤーから噴出する高温空気流を二次元 細線熱電対群プローブ上ですばやく円運動させて，そ の温度場を測定した. 使用したへアドライヤーの高温 空気流の最高温度は約 $70^{\circ} \mathrm{C}$, 出口流速はおおよそ 6 $\mathrm{m} / \mathrm{s}$ である.

図 5 に素線径 $51 \mu \mathrm{m}$ の熱電対群により測定された温 度場の時間変化を示す，図 5(a), (b) はそれぞれ応答 補償前と補償後の結果であり, 温度場の等高線分布が $0.05 \mathrm{~s}$ ごとに変化する様子を表している. 図 5(a) の応 

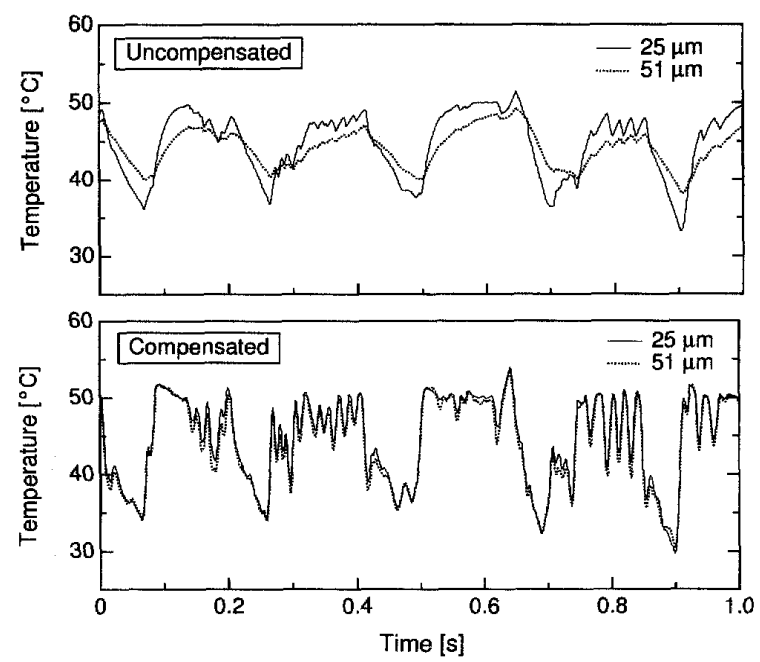

Fig. 3 Response compensation of thermocouple measurements sampled at $(i, j)=(4,5)$

答補償前の温度分布では，熱電対の応答遅れ（利得の 低下）に起因して最高温度が実際より $30^{\circ} \mathrm{C}$ ほど低く 測定されているために，噴流の温度分布とは大きく異 なる緩やかな分布形状となる，一方，図 5(b) に示す応 答補償後の温度分布では, 応答補償によって噴流の中 心温度 (約 $70^{\circ} \mathrm{C}$ ) が正しく再現されるとともに高温 領域が鮮明になって，噴流が円弧上を移動していく様 子が的確に捕捉されている.

注目されることは, 図 5 の時刻 $t=0.05 \mathrm{~s}$ に見られ るように, 応答補償の前後で温度分布のピークの位置 に顕著なずれが生じていることである，すなわち，态 答補償前の図 5(a) ではこのピークが $x=8 \mathrm{~cm}, y=10$ $\mathrm{cm}$ に位置するのに対して，応答補償後の図 5(b) では $x=10 \mathrm{~cm}, y=8 \mathrm{~cm}$ にある. これは噴流が高速で移動 することにより，熱電対の応答における時間的な遅れ が空間的な位置のずれとして現れたことを示す．この ように，応答補償によって噴流の最高温度が正しく再 現されると同時に温度分布の空間的な位相遅れが補償 される結果として，噴流の位置が的確に捕捉されるこ とが分かる.

\section{5. 瞬時時定数の推定}

二次元細線熱電対群プローブのように多数の二線式 熱電対を使用する場合には, 式 (5) の時間平均を熱電 対の配置に対応する空間平均に置換できる. この操作 によって, 時定数の推定と応答補償を測定終了後の後 処理で行う従来の方法とは異なり, 式 (5) 中の時間微 分 $G$ の計算に必要な先行時間 (本実験では時系列デー タ 10 点に対応する $10 \mathrm{~ms}$ である. この計算には多項式 適合法 ${ }^{(6)}$ を用いる）が経過した後には，ほぼ実時間゙で

*最近のパーソナルコンピュータの性能であれば，式 (6) の計算 および応答補償の信号姏理に要する時間はほとんど無視できるの で, 理論的には先行時間の半分 (本奏験では $5 \mathrm{~ms}$ ) の遅れで応答 補償できる。
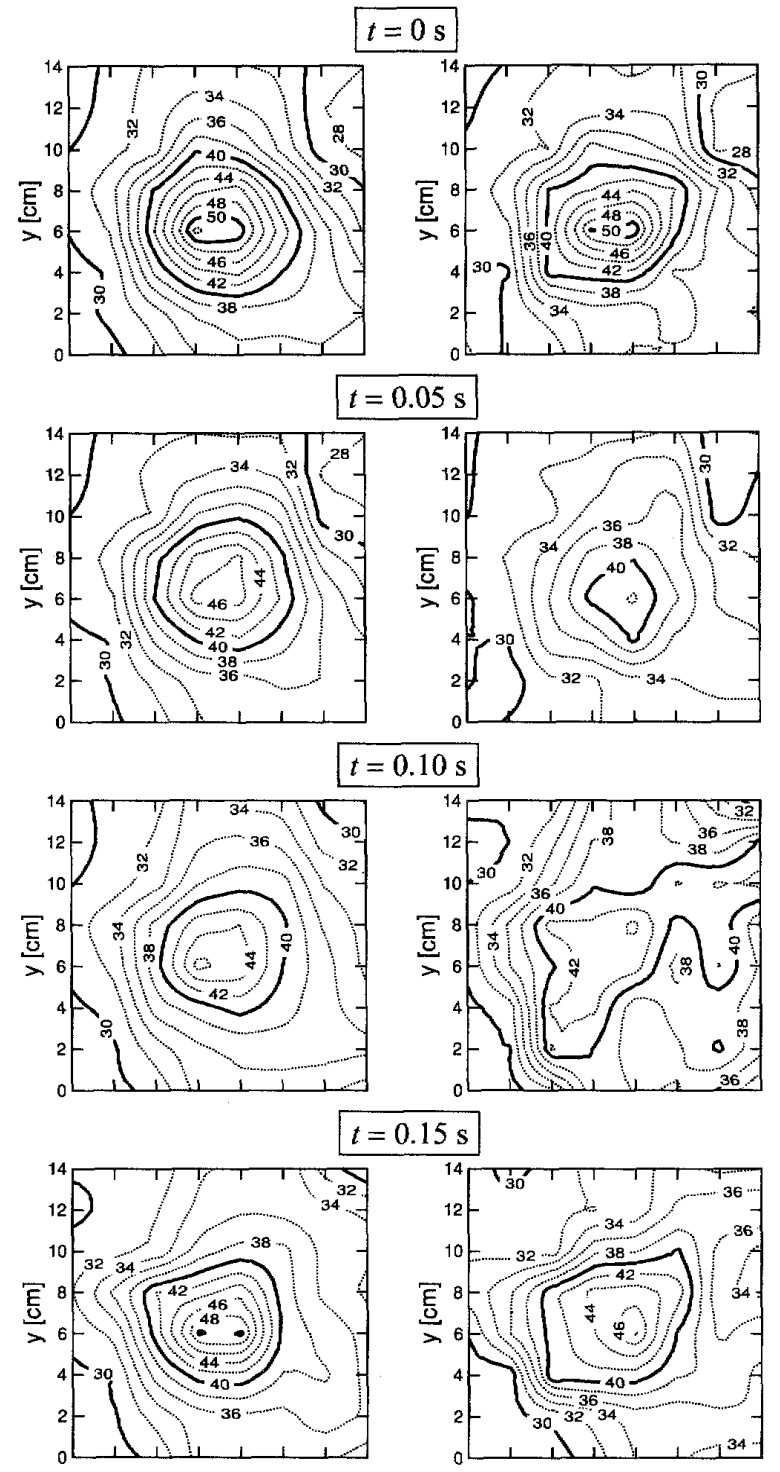

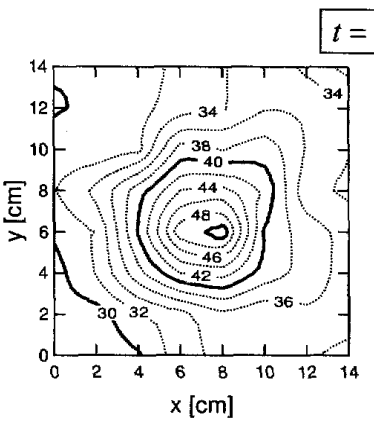

(a) Uncompensated

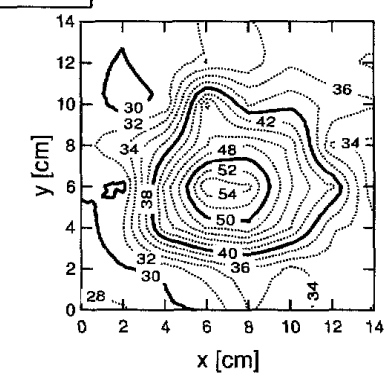

(b) Compensated
Fig. 4 Two-dimensional visualization of a fluctuating temperature field measured with $51 \mu \mathrm{m}$ thermocouples (contours in Celsius scale)

の忘答補償が可能となる.

以上から, 瞬間的な時定数 $\tau_{1}(t), \tau_{2}(t)$ は次式で推定 される. 本研究ではこのようにして推定される時定数 

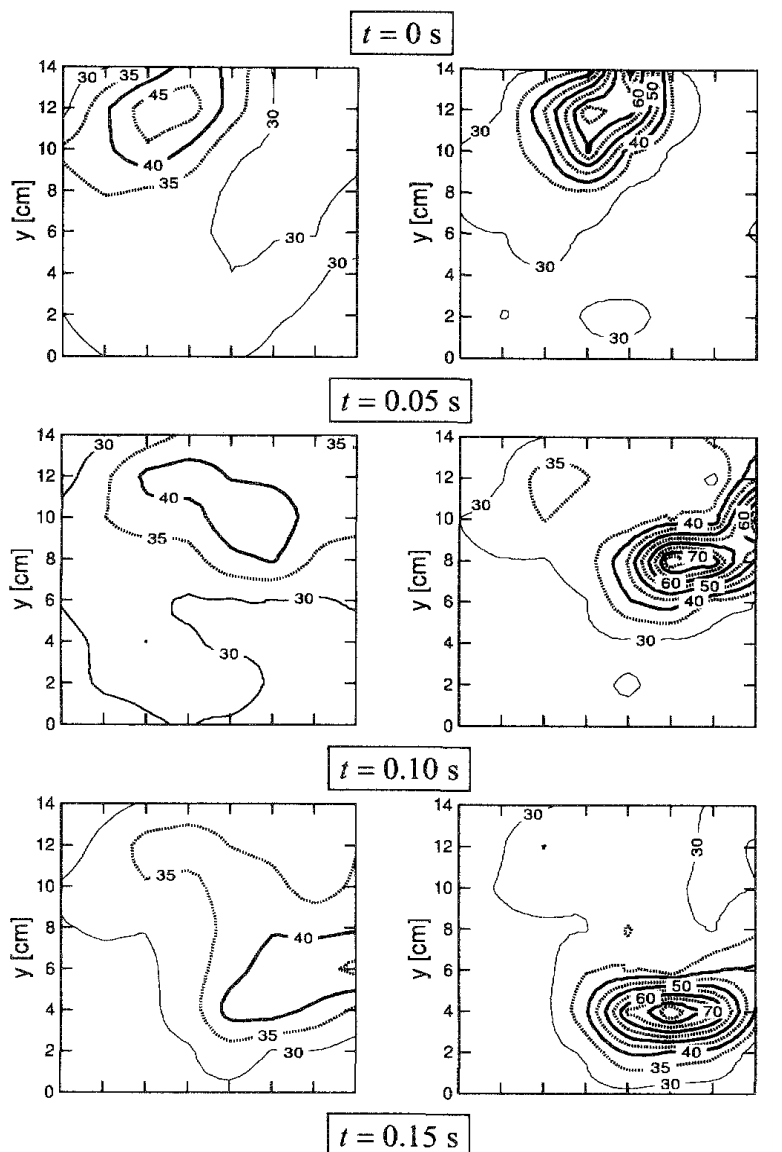

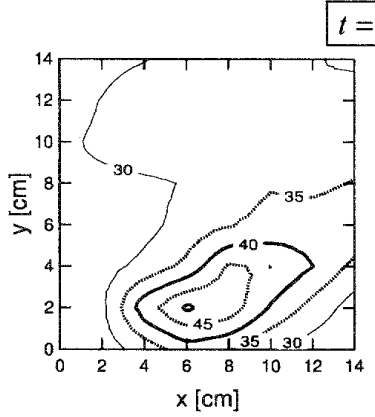

(a) Uncompensated

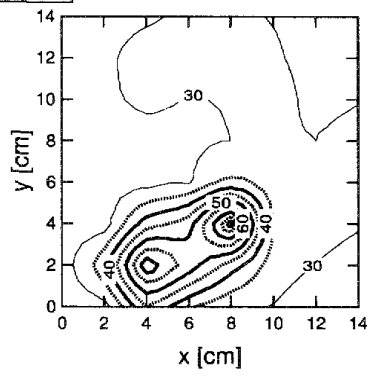

(b) Compensated
Fig. 5 Spatiotemporal behavior of the temperature field of a precessing hot-air jet $\left(d_{2}=51 \mu \mathrm{m}\right.$, contours in Celsius scale)

を瞬時時定数とよぶ.

$$
\left.\begin{array}{rl}
\tau_{1}(t) & =\frac{\sum G_{2}^{2} \sum G_{1} \Delta T_{21}-\sum G_{1} G_{2} \sum G_{2} \Delta T_{21}}{\sum G_{1}^{2} \sum G_{2}^{2}-\left(\sum G_{1} G_{2}\right)^{2}} \\
\tau_{2}(t) & =\frac{\sum G_{1} G_{2} \sum G_{1} \Delta T_{21}-\sum G_{1}^{2} \sum G_{2} \Delta T_{21}}{\sum G_{1}^{2} \sum G_{2}^{2}-\left(\sum G_{1} G_{2}\right)^{2}}
\end{array}\right\}
$$

ここで， $\sum$ は $\sum_{0 \leq(i, j) \leq 7}$ を表す. 式 (6) から分かるよ うに, 瞬時時定数の推定には, 二線式熱電対群の各 点 $(i, j)$ が一様に奇与するのではなく, 二線式熱電対 の温度差 $\Delta T_{21}$ が大きく変化する点の寄与が大きくな る.すなわち，温度変動が存在する点のみが時定数の 推定に関与する. なお, 温度変動が検出されない(常
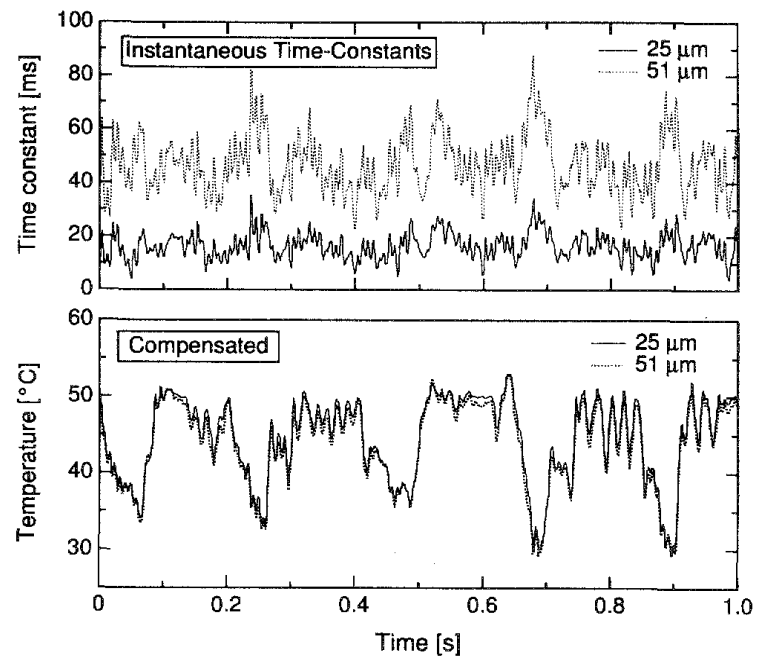

Fig. 6 Signal traces of instantaneous time-constants and temperatures compensated with those values

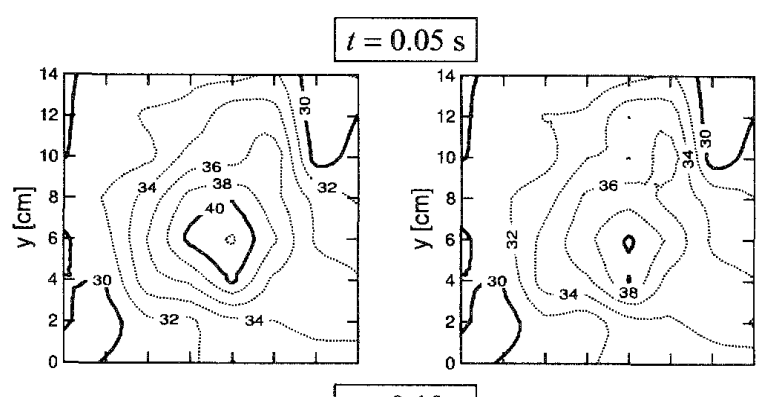

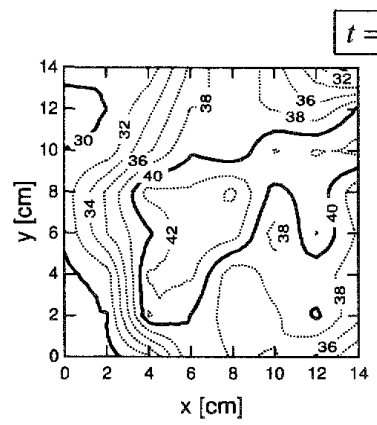

(a) Time-averaged

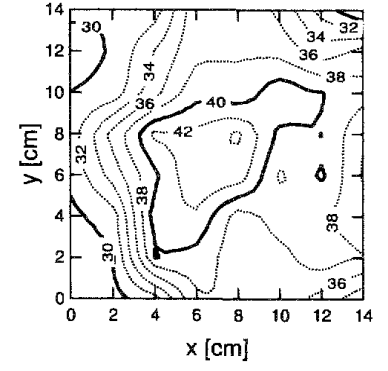

(b) Instantaneous

Fig. 7 Comparison of compensated temperature field between time-averaged time-constants and instantaneous ones (contours in Celsius scale)

に $\Delta T_{21}=0$ となる）格子点では，測定温度の時間微分 $G=\mathrm{d} T / \mathrm{d} t$ も零となるので, 時定数の值にかかわらず 式(1)から常に $T_{\mathrm{g}}=T$ が成立する.

以下では，瞬時時定数による応答補償の効果を 4.2 節で測定された実験データを用いて検証する.

図 6 に, 瞬時時定数の時間変化（上段）と瞬時時定 数を用いた格子点 $(i, j)=(4,5)$ における応答補償後の 温度波形 (下段) を示す. 図60上段から，瞬時時定 
数はかなり大きく変動することがわかる．この変動波 形を下段に示す応答補償後の温度波形と対比すれば, 低温になる時間帯で時定数が増大する傾向が観察され る.この相関は, 図 2 に示すように, 円柱が高温噴流 を周期的に横切ることで温度場を擋乱していることに 起因すると考えられる，すなわち，温度が低下する時 間帯では, プローブの熱電対は円柱によって高温噴流 から遮られる状態にあり，熱電対周りの流速が低下し て時定数が増大すると推察できる。なお，図 6 に示 す瞬時時定数を時間平均した值は，素線径 $25 \mu \mathrm{m} ， 51$ $\mu \mathrm{m}$ の熱電対についてそれぞれ $17.0 \mathrm{~ms}, 48.2 \mathrm{~ms}$ であ り，式(5)による推定值 $19.5 \mathrm{~ms}, 51.3 \mathrm{~ms}$ とほぼ合致 する.

次に, 素線径 $51 \mu \mathrm{m}$ の二次元細線熱電対群で測定さ れた温度分布を対象として，式 (5)の時間平均時定数 および式 (6) の瞬時時定数で応答補償した。結果をそ れぞれ図 7(a), (b) に示す. 図 7 から，時間平均時定 数と瞬時時定数を用いて応答補償した温度分布の間に それほど顕著な差違は見られず，いずれの手法でも温 度場の挙動を再現できることがわかる。したがって， 後処理でよければ時間平均時定数で, 測定領域内での 空間平均的な流速の変化に対応できるように実時間で 処理する必要があれば瞬時時定数でそれぞれ応答補償 すればよい.

\section{6. 一次元細線熱電対群による温度場の可視化}

6.1 一次元細線熱電対群プローブ ここでは, 上 述の結果を基礎として，一次元細線熱電対群プローブ による温度場の可視化計測法を提案する. 本プローブ では，素線径 $25 \mu \mathrm{m}$ と $51 \mu \mathrm{m}$ の $\mathrm{K}$ 熱電対で構成され る合計 24 個の二線式熱電対を, 感温部の長さが 115 $\mathrm{mm}$ となるように $5 \mathrm{~mm}$ 間隔で黄銅棒に配列した。 本 プローブで高温気流をスキャンすることにより，温度 分布を空間一次元と時間の二次元で可視化できること から，ここで提案する手法を以下では「流体温度場久 キャナ」と呼ぶ.

6.2 一次元プローブによる温度場の可視化計測 図 2 の温風風洞で形成される円形噴流において，噴 流軸と直交する面内で上記の一次元プローブを一定速 度で移動させることにより温度場をスキャンする．本 測定のサンプリング周波数は $1 \mathrm{kHz}$ ，データ長は各セ ンサあたり 1024 点である。

図 8 に素線径 $51 \mu \mathrm{m}$ の熱電対群で測定された応答 補償前後の結果を示す. 図 8 の上段と下段はそれぞれ 応答補償前と補償後の温度分布を表す．図の縦軸は 24 個の二線式熱電対の位置であり，横軸は時間である. これによって測定対象の温度分布を空間一次元と時間 の二次元で可視化できる.

4.2 節で述べたように, 本実験で使用した高温空気 噴流の温度場は $52^{\circ} \mathrm{C}$ でほぼ一様である.しかし, 図

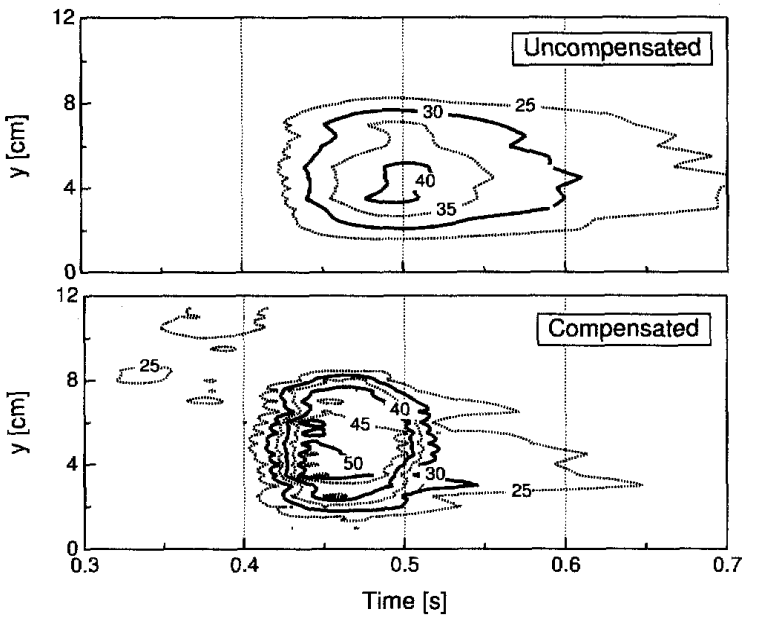

Fig. 8 Quasi two-dimensional visualization by a onedimensional probe (contours in Celsius scale)

8 上図に示されているように，応答補償前の最高温度 は $40^{\circ} \mathrm{C}$ 程度に留まり, 噴流温度の $52^{\circ} \mathrm{C}$ に到達しな い.さらに, プローブが噴流を通過した後でも測定值 は緩やかに低下し続けて，温度分布はすい星のように 尾を引いている.これらの現象は熱電対の応答遅れが 温度分布に反映した結果である。一方，図 8 下図の応 答補償後の温度分布では, 最高温度が $52{ }^{\circ} \mathrm{C}$ に到達す るとともに, 温度分布は噴流形状をほぼ正しく表して いる．また，応答補償前に見られるすい星の尾に似た 温度分布も応答補償によってかなりの部分が消失する. ただし，若干は残存する．この残存は，プローブが噴 流を通過した直後に熱電対周りの流速が急減して, 時 定数が急増するために発生すると考えられる，すなわ ち, 式 (5) で推定された平均時定数 (一定值) ではこ のような時定数の急増には十分には対応できないため に, 応答補償量が不足して発生すると推測される. 実 際に，噴流通過直後の時間帯では，本来一致すべき 25 $\mu \mathrm{m}$ 熱電詨と $51 \mu \mathrm{m}$ 熱電対の応答補償後の温度波形に は若干のずれが生じることを確認している．このよう な問題を除けば，本研究で述べたように一次元プロー ブの出力を適応応答補償することにより, 原理的には, 測定対象場の流速やスキャンの速さによらず同一の温 度分布が再現される。

\section{7. 結言}

本研究では, 多数の二線式熱電対を一次元に配列し た棒状プローブと二次元に配置した平面プローブを それぞれ製作し，それらで取得された測定データに適 応応答補償法を適用することにより, 空気流の温度場 を可視化計測する方法を提案するとともに，その有効 性を検証した. 64 個の二線式熱電対を二次元格子点 (8×8) 上に配置した平面プローブでは, 時空間的に変 化する高温空気噴流の挙動を正しく捕捉できることを 


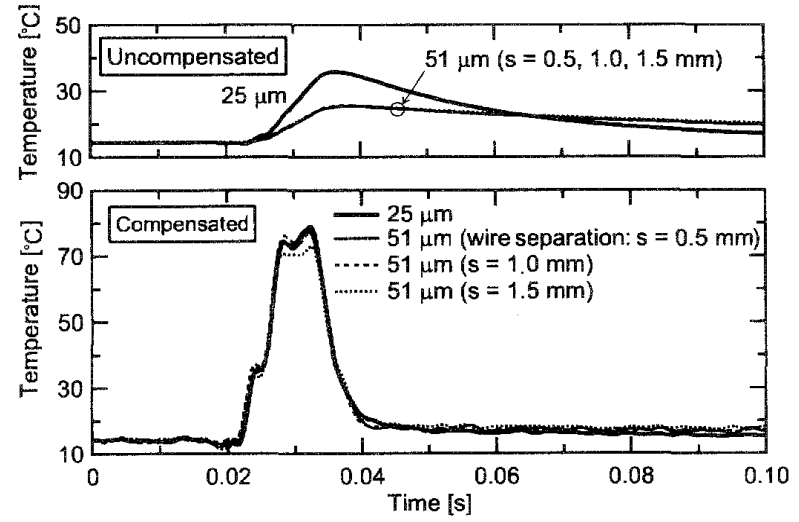

Fig. 9 Effects of wire separation, $s$, between $25 \mu \mathrm{m}$ and $51 \mu \mathrm{m}$ thermocouples on uncompensated and compensated temperatures

実証した。また。多数の熱電封を同時に使用する場合 には, 時定数推定理論における時間平均操作を空間平 均に置換できることを見いだして，時定数の推定と応 答補償を従来のような後処理ではなく、データ収集中 にほぼ実時間で実行する方法を提示した，さらに，24 個の二線式熱電対を直線上に等間隔で配列した棒状プ ローブで高温気流をスキャンすることにより温度場を 可視化する方法を開発し，その有効性を検証した。こ の方法は，棒状プローブの空間的な位置を 1 2 台の $\mathrm{CCD}$ 力メラで画像計測すれば測定対象の 2 3 次元空 間に温度分布を重小て提示できる「流体温度場スキャ ナ」の原型となる。

\section{謝辞}

本研究の一部は科学研究費補助金 [基盤研究, No. 19560202, 22560194]によった.

\section{[付録＼cjkstart線間隔が応答補償に及ぼす影響]}

素線径 $25 \mu \mathrm{m}$ と $51 \mu \mathrm{m}$ で構成される三線式熱電対 の線間隔が時定数の推定と応答補償に及ぼす影響を調 べる、線間隔 $s$ が異なる 3 組の二線式熱電対プローブ 上 $(s=0.5,1.0,1.5 \mathrm{~mm})$ を 4.3 節の高温空気噴流が同時 にすばやく横切った場合の温度変動波形の測定結果を 図 9 に示す。図90上段は応答補償前の変動波形であ るが，3つの51 $\mathrm{m}$ の熱電対の波形に線間隔による違 いはほとんど認められない。このとき，二線式プロー ブとして時定数を推定した結果を表 1 に示す. 間隔 $s$ が $0.5 \mathrm{~mm} ， 1.0 \mathrm{~mm}$ の場合には，推定される時定数に 差異はほとんど現れないが，間隔を $1.5 \mathrm{~mm}$ まで広げ ると時定数は小さく推定される，このことは，補償さ れるべき本来の温度変動信号だけでなくノイズおよび
Table 1 Effects of wire separation on estimation of time constants

\begin{tabular}{c|c|c}
\hline \multirow{2}{*}{$\begin{array}{c}\text { Wire separation } \\
s[\mathrm{~mm}]\end{array}$} & \multicolumn{2}{|c}{ Time constant [ms] } \\
\cline { 2 - 3 } & $\tau_{1}(d=25 \mu \mathrm{m})$ & $\tau_{2}(d=51 \mu \mathrm{m})$ \\
\hline 0.5 & 21.1 & 48.9 \\
1.0 & 21.4 & 49.0 \\
1.5 & 19.4 & 47.2 \\
\hline
\end{tabular}

無相関の高周波数成分が応答補償によって同時に増幅 されるため，空間分解能が低下すると，式 (5)による 時定数の推定值が真值より小さくなるためである(7). 表 1 の時定数で応答補償した温度波形を図 9 の下段に 示す。間隔が $1.0 \mathrm{~mm}$ 以下の場合は互いによく一致す るが，間隔が $1.5 \mathrm{~mm}$ になると補償量が不足するため 温度のピークが小さく推定される。

以上により，本実験で使用した線間隔 $0.5 \mathrm{~mm}$ のプ ローブが十分な空間分解能を有することが示された.

\section{文献}

(1) Taylor, A. M. K. P. (ed.), Instrumentation for Flows with Combustion, (1993), Academic Press.

(2) Tagawa, M., Fine-Wire Temperature Sensors for Measuring Temperature Fluctuatons of a Fluid (in Japanese), Kensa Gijyutsu, Vol. 14, No. 1 (2009), pp. 1-10.

(3) Kato, K. and Tagawa, M., Numerical Evaluation of Response Compensation Techniques for Fine-Wire Temperature Sensors (in Japanese), Transactions of the Japan Society of Mechanical Engineers, Series B, Vol. 73, No. 728 (2007), pp. 1059-1067.

(4) Tagawa, M. and Ohta, Y., Two-Thermocouple Probe for Fluctuating Temperature Measurement in CombustionRational Estimation of Mean and Fluctuating Time Constants, Combustion and Flame, Vol. 109, No. 4 (1997), pp. 549-560.

(5) Kato, K., Tagawa, M. and Kaifuku, K., Fluctuating Temperature Measurement by a Fine-Wire Thermocouple Probe: Influences of Physical Properties and Insulation Coating on the Frequency Response, Measurement Science and Technology, Vol. 18 (2007), pp. 779-789.

(6) Savitzky, A. and Golay, M. J. E., Smoothing and Differentiation of Data by Simplified Least Squares Procedures, Analytical Chemistry, Vol. 36, No. 8 (1964), pp. 1627-1639.

(7) Tagawa, M., Shimoji, T. and Ohta, Y., A TwoThermocouple Probe Technique for Estimating Thermocouple Time Constants in Flows with Combustion: In Situ Parameter Identification of a First-Order Lag System, $R e$ view of Scientific Instruments, Vol. 69, No. 9 (1998), pp. 3370-3378. 